\title{
BETWEEN NEOLIBERALISM, MOTHERHOOD AND DICTATORSHIP: WOMEN'S CITIZENSHIP AND PARTICIPATION IN LATIN AMERICA
}

\section{Neoliberalizm, Annelik ve Diktatörlük Arasında: Latin Amerika'da Kadın Yurttaşlığı ve Katılım}

\section{Elif GÖZLER ÇAMUR*}

Keywords:
Latin America,
Women, Citizenship,
Gender Quotas,
Motherhood,
Participation

JEL Codes: N36, J16, K38

Anahtar Kelimeler: Latin Amerika, Kadın, Yurttaşlık, Kadın Kotas1, Annelik, Katılım

JEL Kodları: N36, J16, K38

\begin{abstract}
Historically and traditionally women experience rights violations more widely and this caused them to practice an indirect citizenship form. Hence, a gendered perception has emerged to understand civil, political and economic rights of women apart from the general notion of citizenship. In this paper, the notion of women's citizenship and its reflections in Latin America will be examined together with examples from women movements, motivations and claims. Although women in different geographies passed similar paths in order to achieve equal rights, every experience has its uniqueness. What makes the Latin American example special are unique motives and environments such as dictatorship, the Church, motherhood and neoliberalism. In this paper, firstly, women's citizenship with a gendered viewpoint is stated. Then, the Latin American women's claims and what mobilise them on realising equal citizenship were explored along with the concepts such as motherhood, religion, military regime and neoliberal transition. Finally, women's political participation in formal politics and civil society is indicated with a special emphasis over quotas as commonly adopted measure to increase the level of women representation in formal politics. Also, women's movements during the military regime and neoliberal process were stated with examples of women organisations from countries in the region.
\end{abstract}

\section{Özet}

Kadınların tarihsel ve geleneksel olarak deneyimlediği hak ihlalleri, onların dolaylı bir yurttaşlık yaşamasına sebep olmuştur. Bu nedenle, kadınların sivil, politik ve ekonomik haklarını inceleyen, genel yurttaşlık olgusundan ayrı bir alan olan "kadın yurttaşlığı" kavramı ortaya çıkmıştır. Bu yazıda kadın vatandaşlığı kavramı ve Latin Amerika'daki yansımaları kadın hareketlerinden ve eşit yurttaşlık taleplerinden örneklerle birlikte incelenecektir.

Farklı coğrafyalardaki kadınlar, aynı eşit hakları elde etmek için benzer yollardan geçmiş olsalar da, her deneyimin kendine özgü yanları vardır. Latin Amerika örneğini özel kılan, kadınların eşit vatandaşlık haklarını kazanma yolundaki hareketlerini şekillendiren diktatörlük, kilise, annelik ve neoliberal politikalar gibi benzersiz motifler ve ortamlardır. Bu yazıda ilk olarak kadın yurttaşlığının genel yurttaşlık bakış açısından farklılaşması bir giriş olarak belirtilmiştir. Daha sonra Latin Amerika'da kadınların eşit yurttaşlık talepleri ve onları harekete geçiren etkenler araştırılmış ve bunlar annelik, Kilise, askeri rejim ve neoliberal geçiş gibi kavramlar çerçevesinde bir anlatıyla belirtilmiştir. Son olarak, kadınların siyasete ve sivil topluma katılımı, resmi siyasette kadın temsil düzeyini artırmak için yaygın olarak benimsenen bir önlem olarak kotalara özel bir vurgu yapılarak anlatılmıştır. Ayrıca askeri rejim ve neoliberal süreçte kadın hareketleri bölge ülkelerinden örneklerle dile getirilmiştir.

\footnotetext{
* Asst. Prof., İzmir Demokrasi University, elifgozler1 @ gmail.com, ORCID: 0000-0003-2394-1447

Makale Geliş Tarihi (Received Date): 21.01.2021 Makale Kabul Tarihi (Accepted Date): 28.03.2021
} 


\section{Introduction}

Women's citizenship rights happened to be gendered due to the unequal separation between public and private spheres. As women continue to be the only caretaker in the private sphere, notions directly related to the citizenship which is built upon the public sphere, such as politics and labour were kept away from women's presence. Since women's rights have been violated traditionally and historically, a need emerged to examine the women's citizenship apart from the general notion of citizenship. Women's low representations in the parliaments or the fact that women still struggle for equal pay for equal work are the concrete examples of such violations. Citizenship is an institution reflecting an interaction between state and the citizen, thus shaped by historical, political and cultural backgrounds. It's gendered version also embodies many paths and challenges faced by women. Although women in different geographies have passed similar paths in order to achieve the same equal rights, every experience has its uniqueness. What makes the Latin American example is special are unique motives and environments such as dictatorship, the Church, motherhood and neoliberal policies that shaped the women's movements on their path to gain equal citizenship rights. In this paper, women's citizenship with a gendered viewpoint is stated as an introduction. Here, citizenship as a gendered concept is indicated within the framework of Marshall's classification along with its gender-based weakness. Through this classification, women's citizenship claims for political, social and civil rights are explained along with related examples. Then, the Latin American women's claims and factors that mobilise them on their path to realising equal citizenship were explored along with the concepts such as motherhood, the role oh the Catholic Church, military regime and neoliberal transition. The controversial function of the Church for the women's right and motherhood as a type of activism is explained first, then the impact of neoliberal policies especially on social rights of women is shown. Finally, women's political participation in formal politics and civil society is indicated with a special emphasis over quotas as commonly adopted measure to increase the level of women representation in formal politics. Also, women's movements during the military regime and neoliberal process were stated with examples of women organisations from countries in the region such as Brazil and Chile. This study does not require permission from the ethics committee. Research and publication ethics were followed.

\section{Gendered Citizenship}

Women enjoying equal citizenship rights as men is relatively a new development. In ancient Greece, they have been excluded from basic citizenship rights, such as voting, together with the slaves and the outsiders (Lister, 2003, p. 69). Until recently, almost all basic political thoughts were gender-blind. Rousseau, the leading advocate of participatory democracy and social equity, found no incompatibility in precluding women from citizenship and from political rights (Navarro and Bourque, 1998, p. 175). During the French Revolution, women also demanded equal rights and tried to create their own revolution as well. However, their ideas were not welcomed and punished (Mies, 2012, p. 61). They were only accepted as the bearers of the next generations and excluded from the foundational notions, fraternity, equality and liberty.

Despite being identified as gender blind, citizenship theory of Marshall will be referred here for reasons of classification. T. H. Marshall's study, which articulates the modern citizenship as a condition of class inequality, provides a foundation for equal citizenship rights. 
His theory consisted of three dimensions: civil, political and social. In this study, civil citizenship is discussed within the issue related to reproductive rights, social citizenship is discussed within the effects of neoliberal policies and political citizenship is discussed within the political participation of women in Latin America. Summarising the classification of Marshall, civil citizenship referred to individual freedoms, such as the freedom of speech, faith, thought; and rights such as right to justice, property and contract. Political citizenship consisted of rights such as participating in decision-making processes and voting. Social citizenship included the right to welfare and security and to share in the "social heritage and to live in the life of a civilised being according to the standards prevailing in the society" (Marshall, 1950, p. 10-11). Marshall construed class as a pattern of inequality; thus, regarded citizenship as consistent with the inequalities of the social class, yet he overlooks the gender equality. Here the weakness of Marshall's conception of citizenship concerns the paid labour in the public sphere, and the status it grants to workers. This conception ignores the gendered division of labour. If the community is by definition a masculine world of work, then women as responsible of reproductive, unpaid work, excluded from this definition of "community" (Schild, 2000, p. 280). In this respect, instead of a sole "gender-neutral" citizenship conception, Lister (1995, p. 33) offers a different conception of citizenship: "one which combines the gender-neutrality of an approach which seeks to enable women to participate with men as equals in the public sphere (suitably transformed) with a gender-differentiated recognition and valuing of women's responsibilities in the private sphere". Building citizenship over the public sphere may render the problems existed in the private sphere invisible, hence overlook the women's rights as the main caretaker in the private sphere. In this sense, determining the border between public and private spheres and its attributions is very much related to the perceptions towards men and women as citizens. Inequality in the private sphere reflected itself as equality for men in the public sphere (Çakır, 2019, p. 45).

Women being treated equally and legally as men is constructed upon the successful struggles of women throughout the time. Especially, through the suffragette movement, women mobilised against a popular perception that women do not need to have their own say because their fathers and husband can look their women's interests for their account (Phillips, 2012, p. 40). Rights such as voting, accessing higher education, working and taking down the gendered double standards have been the main objectives of the suffrage movement. Though the successful struggles, women were able to gain the right to vote and have a decent education in many countries around (ECLAC, 2007, p. 16). However, due to unequal separation between public and private spheres which is called as "patriarchal separation" by Pateman (1988, p. 13) and existing gendered perceptions, women representation in formal politics remained low and cautions such as quotas were adopted as a remedy. Like political rights, civil citizenship rights such as freedom of movement have also been gendered. Within the example of the abortion ban, women were deprived of control over their bodies (Franceschet, 2005, p. 19). For instance, in terms of civil rights, in the nineteenth century, under the common law doctrine of covertures, individual rights of women have been ignored. Accordingly, a married woman could not, without her husband's consent, own property or make contracts (Lister, 2003, p. 69). As different from men, dependent and married women lack the freedom to make basic choices. It can be derived from these cases that women actually existed in social life yet dependent on a man. Thus, practised an indirect form of citizenship. The patriarchal separation that Pateman states, reveal itself more apparent within the economic rights. Although women's participation 
in labour market raised significantly, dependency on the man still remains due to the gendered roles in the private sphere. This also caused a wage gap in favour of men as if women are not counted as the breadwinners of the family (Lister, 1991, p. 67). The process of neoliberalism only exacerbated the labour market for women through concepts like precarious employment and flexible working. Thus the struggle to receive equal pay for equal work still remains as an important issue for achieving equal citizenship.

Although women entitled political, social and civil rights equally with men, they practised an absent form of citizenship due to existing perception that renders the public sphere as a male dominated arena. Since, historically and traditionally women are excluded from areas such as working space, civil society, formal and informal politics and even decisions over the female body; they were deprived from realising equal citizenship in practice. Citizenship is an institution shaped by historical, political and cultural backgrounds and its gendered version also reflects a background within. Women in different countries have passed different paths in order to achieve the same equal rights. In Latin American example, unique motives and environments such as dictatorship, motherhood, neoliberalism and the Catholic Church have shaped the women's movements on their path to gain equal citizenship rights.

\section{Women's Citizenship in Latin America}

In Latin America, women's demands passed through various periods. In the late of nineteenth century, feminist groups organised for women to be treated as equals in the public and private spheres. Suffrage movements were also active throughout Latin America. Despite some reforms were introduced over the century, and women gained some sort of equality in the family and work, there were still significant inequalities in all areas of social life. This quasi citizenship, both social and legal, led to discontent like student movements in the 1960s and claims for equality became a voice of rebel. In the 1970s, there were several dynamic popular women's movements but unfortunately overshadowed by military dictatorship with intense violation caused to human rights breaches (Craske and Molyneux, 2002, p. 3). Women's struggle for equality has been one of the most determinant movement on the way to gain democracy and citizenship in Latin America. As happened in similar cases, women in Latin America had to challenge the white, male, western and liberal version of citizenship that preserve male privilege in both public and private spheres (Dagnino, 2006, p. 33). Although women were excluded from political power for a quite long time, they resisted and demanded formal rights arising from citizenship. They gained those rights slowly yet, differed from men's. Nevertheless, they bring forward the reasons behind their exclusion and tried to express the women's value for labour both in private and public spheres (Molyneux, 2001, p. 199).

\subsection{Contested Spaces: Church and Motherhood}

Particularly in Latin America, the Catholic Church has a significant role in women's activism in a contested way. Women were organised under the protective umbrella of the Church, although many groups afterwards left in order to keep their independence or to protests the Church's attitude on certain issues, like divorce and reproductive rights (Jaquette, 1994, p. 4). For example, in Argentina, government programmes on reproductive issues are improved in a context with considerable contributions from religious organisations in the Catholic Church. 
(Møllmann, 2005, p. 18). Through the effects of Catholicism, motherhood became the most important medium for women's justification to demand political and legal rights. As stated by Dominguez Reyes (2004, p. 28), they became "feminist maternalists" and render their motherhood as service to the nation. Despite its mobilisation ability, the Church also has a negative attitude, especially on women's reproductive rights. As concluded by Jelin (1998, p. 183) "Ideological traditionalism of the Catholic Church, along with the practices and ideologies that implicate the victim, have hindered the implementation of legislation, public health programs and educational services that might otherwise counter such oppression". In short, the Church as a leading community subject may have an awareness of women's citizenship right but it also ignored their womanhood through neglecting reproductive rights.

Besides political and social rights, it should be stressed that as a civil right, the issue of abortion takes an important part in Latin American women citizenship. In terms of the citizenship concept, women have the right to exercise on their own bodies. According to Willmott (2002, p. 133) "it isn't possible to exercise citizenship in relation to the world if one hasn't learnt to exercise citizenship in one's own body. So the abortion is an issue that severely limits women's citizenship". Unfortunately, Nicaragua is one of three countries in the world to preserve an extensive prohibition on abortion, even in the situations of rape, incest, or life- or health-threatening pregnancies. Such extensive abortion bans are conflicting with international human rights obligations, including obligations on the rights to life, health, and nondiscrimination. Such enforcement can, and often does, have critical effects on the lives and health of women and girls (Møllmann, 2007, p. 1). Abortion is still a problem in Latin America, even in leftist governments which should be concerned about this issue naturally. However, the pressures from the Catholic Church seems to be unbreakable and still influential on women's own bodies. As reported approximately, 6.5 million abortions exercised in Latin America every year and nearly three-quarters of them performed in unsafe and illegal environments (Latin America's fight to legalise abortion: the key battlegrounds, 2018). Out of 33 states, only Argentina, Cuba, Uruguay and Guyana legalise abortion in Latin America (The World's Abortion Laws, 2021). Although the right to abortion is defended by feminists from the 1980s, the movement was halted due to the military regime and the vulnerable democracy dominated by the conservatism. Since then, it is still a major subject for the women's agenda in Latin America. Most recently, in December 2020, Argentina became the last country to legalise abortion (Arjantin'de kadınlar kürtaj hakkını nasıl kazandı?, 2021).

Motherhood, as an important action repertoire, has a significant role in Latin American women mobilisation. For instance, women become activist mothers in toxic waste protests, after detecting the impact on their families' health. Hence women use traditional female identities to take legitimate actions to improve their communities and the lives of their families. Adopting motherhood as a legitimising identity can be considered within the concept of "patriarchal bargaining" by Deniz Kandiyoti (1988). Accordingly, as a strategy women prefer to embrace traditional values to gain protection and security. In this respect motherhood acted as shield for women to legitimise their protests over various occassions. As told by Lister (2003, p. 148), "women who previously did not see themselves as in any way political are becoming advocates for social change." As stated by Dominguez Reyes (2004, p. 28), "from the beginning women's rights were social rights associated to the protection of the family and the 'race': equality and protection were combined. Equality was understood as a consequence of 'feminine' responsibilities. And from history up to today all political movements adhere to these 
'motherist' images: from the right to the left. Even among the left and guerrillas movements the image of women is always associated to mothering.", The most well-known example of mothering is Madres de Plaza de Mayo in Argentina, their protest is against the disappearance of their children and husbands. Military regime, as the responsible for the disappearances represent itself the patriarchal guardian of the family, social body, fatherland (Nelson, 2002, p. 41). In these times, women's movements had a significant part in the breakdown of authoritarian rule. During the dictatorship, women's movements asked citizenship rights in all terms and organised multiclass movements. "Women's organisations had been part of the opposition to military rule, but had to rethink their anti-statist position under the new conditions of transition and consolidation" (Waylen, 2000, p. 771). Therefore, they prepared themselves for the full form of citizenship and raise awareness. According to Franceschet, Piscopo and Thomas (2015, p. 3), maternalism still has an impact over current political environment: "Maternalism's emphasis on caretaking, compassion and domestic management still shapes the public's response to female political leaders. We argue that maternalism's enduring power means that today's female politicians, irrespective of their individual experience or identities, often frame their office-holding ambitions and their policy preferences in culturally acceptable, gendered terms." Once started as a pattern for women's rights movements, motherhood reproduces itself against the oppression of the military regime and still effective for women's participation in formal politics.

\subsection{The Impact of Neoliberal Policies}

It is not only the military regime but the implementation of neoliberal policies in the 1980 s affected the women's citizenship especially in terms of social rights. Structural adjustment policies as a solution to economic crises, hit the urban poor, especially women significantly. In the 1970s and early 1980s, the mass protests of women proved that the military regime's economic policies had not been succeeded (Jaquette, 1994, p. 3). The shift from welfare state to the neoliberal state undermined the social rights as a prime condition of exercising full citizenship in Marshall's terms. This transformation also threatens the ideals of political equality because it is founded on wealth and income inequality (Molyneux, 2001, p. 201). The neoliberal economic order, concreted by the structural adjustment programmes, commenced a period of economic crisis and declining living standards for both poor and the middle class. This process also affects the existing political and social agenda within the framework of expanding citizenship rights. Hence, women as one of the major vulnerable groups to such social and economic change have expressed their demands and mobilised in order to enjoy their civil, social and political rights equally with men (Franceschet and Macdonald, 2003, p. 1). Through the 1980s, the restrictions, contradictions and fragilities of women's spaces in a paternalistic, racist and neoliberal capitalist state became increasingly clear (Jaquette, 1994, p. 53). To clarify how neoliberal economics affects women's political participation, Craske's two distinctions can be comprehensive. Firstly, within the gender-blind and masculine framework of the neoliberal project, women's unpaid labour is neglected. Hence, it ignores challenges that women have to deal with and does not create a variety of opportunities to enable their participation in politics and labour. Second, in the case of Latin America, it promotes a comparative advantage based on cheap labour, often with the impetus for temporalization of production, reflecting many of the features of women's employment practices in the region. Especially in growing industries like textile and electronics, the majority of the 
labour force is women who accepted export-led development's conditions. The new economic regime extended women's participation in waged labour, but since women's wages generally stay lower than men's, women had to work longer hours to maintain family needs, and conditions often became worse (Craske, 1998, p. 106). While women's movements look to extend the meaning of citizenship including social rights that are guaranteed by states, neoliberal governments adopt an argument of citizen activism to foster society to provide its own solutions for economic suffering and poverty (Franceschet and Macdonald 2003, p. 2). In this new order, while women had access to education and health, and entered the labour force, their primary duties remain the same within the family, thus liberal citizenship might broaden women's space in the public domain, but in the private realm, a different order dominated (Molyneux, 2006, p. 427). In short, "Neoliberal project depends on women retaining their "traditional" family oriented identities without undermining their availability for the labour market to provide long-wage competition" (Craske, 1998, p. 114). Still, in contrast to the "masculine" policies of the public domain, welfare states have sometimes concerns about feminist approaches, particularly in the first world. As campaigners and welfare providers, they progressed in welfare state development so that the welfare state has offered an important domain for the expression of women's political citizenship, stressing its connections with social citizenship. However there are contradictions of welfare states that, while providing women with a degree of economic independence, they, at the same time, tend to transform them into economic dependants, thus undermining their economic independence (Lister, 2003, pp. 168, 171).

\subsection{Political Participation}

Following the military dictatorships in Latin America, women sought new platforms to enhance the opportunities for political participation. During the post-authoritarian period where the interaction between civil society and the state is increased, women's movements mobilised not only in the margins but also in central formal politics. Moreover, they engaged with international organisations as well as pan-Latin American organisations (Molyneux, 2001, p. 201). The process of achieving democratic citizenship was a slow change for Latin American women. It began in Ecuador in 1929 and lasted in Paraguay in 1961. In only four countries women gained political rights before 1940 (Ecuador, Brazil, Uruguay and Cuba), the rest did so in the 1940s and 1950s. In most countries, the right to vote was primarily limited to educated women. Therefore, in countries which have the most indigenous population, like Bolivia and Guatemala, these limitations were severe for a very high percentage of women, and illiterate women could not vote until the 1980s (Navarro and Bourque, 1998, p. 177). According to Craske (1999, p. 3), following factors can explain women's exclusions from politics: Authoritarian Latin American political systems have discouraged mass participation except for moments of populism; the common belief that politics is part of a man's world and inappropriate for women and this has concluded in women's political inclusion meant being ignored, as it has been explained as a social rather than political issue. As women continue to opt-out of traditional politics, the practice of citizenship remains a masculine activity and a vicious circle emerges (Craske, 1999, p. 210). As a solution for this problem quotas were introduced for formal politics. Quotas are the primary mechanism for carrying out gender balance in political institutions. Also called as "electoral candidate quotas" or "legislature sex quotas", quotas were designed to ameliorate the under-representation of women. Quotas 
required various mechanisms that intend to secure gender-balanced decision-making, like party quotas that intend to augment the number of women party candidates and legislative quotas that entail political parties to select a particular percentage of women among their candidates. From this perspective, although quotas have a positive effect on women participation, it should be implemented carefully. According to Squires "quotas prove a loose, unpredictable form of group representation, they have proven to be controversial, frequently perceived to undercut a normative commitment to fairness and equal opportunities, and, more concretely, to limit the political opportunities of incumbent candidates or potential male aspirants." (Squires, 2007, p. 24). In Latin American case, quotas have been only slightly effective in increasing the number of women elected to Latin American legislatures. In eleven countries with quotas, women made an average of 9 per cent of the legislature before to the quota. After practising the quota, this extends to 14 per cent. In other words, quota have increased women's existence by five percentage points (Htun and Jones, 2002, p. 37). Countries have responded diffently to the quota system in the region. For instance, Argentina was the first country to implement quotas in 1991 and by 2002 had 30.7 per cent women representatives in the Chamber of Deputies and 35.2 per cent in the Senate which appears as an successfull implementation. On the other hand, Costa Rica, which has the highest quota by $40 \%$ had just $19.3 \%$ women in the parliament. To overcome such low rates, following the decision of Supreme Electoral Tribunal in 2002, parties started to place women candidates in winnable positions and as a result the rate o women in parliament increased to 35\% (Peschard, 2003, pp. 23-24). Another example is Cuba, although does not implement quotas, they have $\% 53$ women MPs in the parliament by 2021 (Monthly ranking of women in national parliaments, 2021). These data show that although systems such as quotas have a positive impact in enhancing the number of women in Parliaments, political histories and cultures also play a unique role in realising a sincere implementation. Indeed, a recent study shows that, parties started to place more women candidates in Latin America when citizens's trust for the government decreased. Mostly beacuse people render women more trustworthy and honest (Funk, Hiojosa and Piscopo, 2019). More parties and governments started to recognise women's demands as justified, political demands. As concluded by Craske (1999, p. 85), "The transition to and consolidation of democracy has provided many opportunities for women to make demands and achieve significant gains in terms of legalinstitutional changes such as social welfare changes, women's ministries and greater representation in political parties through quotas". By 2020, on average $26.4 \%$ of the MPs in Latin American countries are women, where as the global rate is $25.6 \%$ (Global and regional averages of women, 2020). Despite the quotas and all other amendments, the women proportion in administration departments remained belove 30\%. However, countries such as Bolivia, Mexico, Ecuador and Nicaragua accomplished above $40 \%$ as a significant success (Rozas and Floru, 2017).

As Waylen (2000, p. 9) stressed, "Large numbers of women are employed at the bottom of the hierarchy but the numbers decrease as the top of the pyramid is approached. Some parts of the state such as the military and the police are also disproportionately staffed by all men at all levels while women are found only rarely in central banks, economic ministries or foreign trade departments.". Since there are few women in positions at the top of state hierarchies and in decision-making procedures within politics, it can be derived that the state is a gendered frame and that the politics which come out from states are also gendered. As concluded by Güneş Gülal (2019, p. 381), although women participation in formal politics have incresed in Latin 
America, gender based discriminative actions still appears as an obstacle for women's accession in politics.

After the neoliberal transition, the movements separated particularly along class lines, as women were faced with choices on where to focus their activism. While most women continued to play out their activism in the community or local arena, other women chose to enter the formal political arena (Franschet, 2005, p. 8). Apart from formal politics, the participation of women in the social movements is a way of improving political citizenship, through reflecting the direct effect that government policies had on their positions and the way in which the political sphere was changing under the extreme conditions. Social movements have positive outcomes that they block the fear which supported the authoritarian governments and created an alternative way of political activity in the lack of political parties, women's groups, trade unions, student organisations. They also introduced new actors on the political realm, especially women who were generally antipathetic towards institutional politics. Besides, they challenged traditional division between the social and political and between private and public which had strengthen women's exclusion from political life (Craske, 1998, p. 102). In the political arena, both left and right have some kind of antipathy to "women's issues". A significant characteristics of politics in the region is the incapability of social movements to found themselves in the institutional political domain and the lack of crossover between social movement actors and political parties. A leading exception is the Workers' Party in Brazil. There, party members are exacted to preserve a dual militancy, attending in both party and grassroots political organisations (Craske, 1998, p. 110). Another example, former president of Bolivia, Evo Morales, started as the leader of a coca union, then became the leader of Movimiento Al Socialismo (MAS) which is a social movement turned into a political party advocating for indigenous rights in Bolivia (Harten, 2011).

Women's equal participation at all levels of political decision-making is essential to their right to achieve full citizenship. There are several political movements can be named here. For instance, in Chile, intending to do solidarity work with political prisoners and their families, the association of democratic women (Agrupación de Mujeres Democráticas) was established in 1973. During the late 1980s, the Agrupación extended its domain of political activities but its principal task always remained as solidarity work with the victims of political repression. As an organisation, it attends in the struggle for democracy; it also defines itself as having leading political roles after turning to democratic rule, likewise encouraging the political education of women so that women could begin to take part in the traditional political organisation as equal as men. (Chuchryk, 1994, p. 71). Again in Chile Women for Life (Mujeres por la Vida) in 1986 demonstrated a statement of women's demands to the Asamblea de la Civilidad (Civil Assembly), in this document, women's claims for democracy with respect for human rights, equal wages, the making of "dignified" jobs and an end to unemployment, right to education, housing and healthcare were mentioned. They demanded free birth control, divorce legislation, and more equal relations within the domestic life. Noting access to the political sphere, they called upon the state to augment women's inclusion in all social and political programmes and within the state. This was the first time that women's claims composed such a basic part of the public agenda (Franceschet, 2005, p. 72). Also, well-known feminists who participated the centre and leftist parties that composed the Concertacion por la Democracia -the first civilian government formed in 1989 after the 1973 military coup- and this women's coalition was 
formed and stated purpose of demonstrating women's claims to the new civilian government (Schild, 1998, p. 100).

Whereas in Brazil, starting in the mid-1970s, both poor, uneducated women and university-educated, middle-class women coordinated movements to push their gender-based political demands on the Brazilian political system. Political liberalisation or abertura in Brazil generated an extended political opportunity for female political participation and for clarifying gender-specific political demands (Alvarez, 1989, p. 205). In 1986, women candidates who were also the members of the women's movement participated in a national conference. This resulted in a Women's Charter stressing on various subjects around discrimination, childcare and the acceptance of motherhood as a "social responsibility", which they committed to keeping if elected (Craske, 1999, p. 79). Another significant movement in Brazil is the Rio Grande do Sul originated, The Movimento de Mulheres Trabalhadoras Rurais (MMTR, Rural Women Workers' Movement), which started their activities in 1989 based on antidam movements, labour unions, land-recovery movements and church organisations. It's main agenda is spreaded from ensuring equality at work and benefits for rural women for reproductive rights, political representation, domestic violence and general women's rights (Stephen, 1997, p. 209). Similarly, in Chile, women in the Seasonal and Permanent Workers' Union of Santa Maria challenged thoughts about the traditional label of their own gender roles. According to Stephen (1997, pp. 244-245), "their political activism has (1) led them to challenge the traditional gendered division of labor, (2) caused them to question their relative power and authority in the family, in local firms, and in formal organizations, and (3) raised issues of reproductive control and sexuality within their homes and organizations.".

\section{Conclusion}

As the identities like being mother and wife, belonging to the private sphere, continue to be attached to women, their existence as the individual citizens will never be realised equally as men in the public sphere. This reflects itself by assigning women to supporting roles, if not banned, in political citizenship rights and excluding from social and civil rights due to performing duties supposed to be realised in the private sphere.

Historically and culturally women in Latin America have suffered from various problems within traditions, macho culture, the order of neoliberal economics, authoritarian regimes and Catholicism. From suffragette movements, protesting disappearances in military regimes as mothers or fighting inequalities of the neoliberal order and to gain reproductive rights, they got the awareness of activism and thus became political actors. Indeed, their activism to enjoy political, social and civil citizenship come a long way. As concluded by Franschet et al. (2015, p. 2), "women now hold nearly 40 per cent of legislative offices in some Latin American countries; they have been credible contenders for or captured the presidencies of the region's most prominent countries; and they have led high-profile ministries and attained seats on constitutional and supreme courts". Participating in formal politics is a must in terms of transforming the existing conditions which undermine the women's equal citizenship. In this respect, women should seek powerful positions and ensure possible changes in the political arena where usually dominated by men. Women in Latin America still fight to pull down the 
patriarchal power structures in all courses of life. Most recently, the "Las Tesis" "movement and their protest style spread around the World and raised awareness against the rape culture. While women continue to be active and mobilise against the sexist power structures in civil society, they should also be in formal politics because necessary legal regulations to ensure equal citizenship can only be achieved through being active in the legislative offices.

\section{Researchers' Contribution Rate Statement}

I am a single author of this paper. My contribution is $100 \%$.

\section{Conflict of Interest Statement}

There is no potential conflict of interest in this study.

\footnotetext{
${ }^{1}$ Las Tesis is a Chilean feminist group, their song "The rapist is you" combined with a special dance gone viral around the World (The rapist is you!': why a Chilean protest chant is being sung around the World, 2020)
} 
E. G. Çamur, "Between Neoliberalism, Motherhood and Dictatorship: Women's Citizenship and Participation in Latin America"

\section{References}

Alvarez, S. (1989). Politicizing gender and engendering democracy. In A. Stepan (Ed.), Democratizing Brazil, problems of transition and consolidation (pp. 205-251). London: Oxford University Press

Arjantin'de kadınlar kürtaj hakkını nasıl kazandı?. (2021). How did the women in Argentina gain the right to Abortion. Retrieved from https://www.indyturk.com/node/294306/dünya/arjantinde-kadınlarkürtaj-hakkını-nasıl-kazand1

Çakır, S. (2019). Erkek kulübünde siyaset [Politics in Men's Club]. İstanbul: Sel Yayınc1lık.

Chuchryk, P. (1994). From dictatoship to democracy: The women's movement in Chile. In J. Jaquette (Ed.), The women's movement in Latin America, participation and democracy (pp.65-107). Oxford: Westview Press.

Craske, N. (1998). Remasculinisation and the neoliberal state in Latin America. In G. Waylen and V. Randall (Eds.), Gender politics and the state (pp. 100-120). London: Routledge.

Craske, N. (1999). Women and politics in Latin America. Cambridge: Politiy Press.

Craske, N. and Molyneux M. (2002). The local, the regional and the global: Transforming the politics of rights. In N. Craske and M. Molyneux (Eds.), Gender and the politics of rights and democracy in Latin America (pp. 1-31). Basingstoke: Palgrave.

Dagnino, E. (2006). Meanings of citizenship in Latin America. Canadian Journal of Latin American and Caribbean Studies, 31(62), 15-51. doi:10.1080/08263663.2006.10816901

Domínguez Reyes, E. (2004). Introduction: On women and citizenship in Latin America and Mexico (pp. 27-41). Retrieved from https://gupea.ub.gu.se/bitstream/2077/3298/1/haina_4_introduction.pdf

ECLAC. (2007). Women's contribution to equality in Latin America and the Caribbean. United Nations. Retrieved from https://repositorio.cepal.org/handle/11362/2833

Franceschet, S. (2005). Women and politics in Chile. Boulder, CO: Lynne Rienner Publishers.

Franceschet, S. and Macdonald, L. (2003). Hard times for citizenship: Women's movements in Chile and Mexico. Paper prepared at the 2003 Canadian Political Science Association Annual Meeting Dalhousie University Halifax, NS. doi:10.1080/1362102042000178382

Franceschet, S., Piscopo, J. and Thomas, G. (2015). Supermadres, maternal legacies and women's political participation in contemporary Latin America. Journal of Latin American Studies, 48(1), 1-32. doi:10.1017/S0022216X15000814

Funk, K. D., Hinojosa, M. and Piscopo, J. (2019). Women to the rescue: The gendered effects of public discontent on legislative nominations in Latin America. Party Politics, 1-13. doi:10.1177/1354068819856614

Global and Regional Averages of Women. (2020). Women averages. Retrieved from https://data.ipu.org/women-averages

Güneş Gülal, A. G. (2019). Latin Amerika'da kadının siyasal ve toplumsal hayattaki rolü. In C. Uysal Oğuz, S. Atvur and R. İzol (Eds.), 21. yüzyılda Latin Amerika. Ankara: Seçkin Yayınları

Harten, S. (2011). The rise of Evo Morales and the MAS. Zed Books.

Htun, M. N. and Jones, M. P. (2002). Engendering the right to participate in decision-making: Electoral quotas and women's leadership in Latin America. In N. Craske and M. Molyneux (Eds.), Gender and the politics of rights and democracy in Latin America (pp. 32-56). London: Palgrave Macmillan.

Jaquette, J. S. (1994). Introduction: From transition to participation-women's movements and democratic politics. In J. S. Jaquette (Ed.), The women's movement in Latin America: Participation and democracy (pp. 1-11). San Francisco: Boulder.

Jelin, E. (1998). Women, gender, and human rights. In E. Jelin and E. Hershberg (Eds.), Constructing democracy: Human rights, citizenship, and society in Latin America (pp.177-197). New York: Westview Press 
Kandiyoti, D. (1988). Bargaining with Patriarchy. Gender and Society, 2(3), 274-290. Retrieved from https://journals.sagepub.com

Latin America's fight to Legalise Abortion: The Key Battlegrounds. (2018). Latin America's fight to legalise abortion. Retrived from https://www.theguardian.com/globaldevelopment/2018/aug/09/latin-america-fight-to-legalise-abortion-argentina-brazil-chilevenezuela-uruguay-colombia-el-salvador-peru

Lister, R. (1991). Citizenship engendered. Critical Social Policy, 11(32), 65-71. doi:10.1177/026101839101103205

Lister, R. (1995). Dilemmas in engendering citizenship. Economy and Society, 24(1), 35-40. doi:10.1080/03085149500000001

Lister, R. (2003). Citizenship: Feminist perspectives. London: Palgrave Macmillan.

Marshall, T. H. (1950). Citizenship and social class. Cambridge University Press.

Mies, M. (2012). Dünya ölçeğinde ataerki ve birikim: Uluslararası işbölümünde kadınlar (Çev. Y. Temurtürkan). İstanbul: Dipnot Yayınları.

Møllmann, M. (2005). Decisions denied, women's access to contraceptives and abortion in Argentina. Retrieved from https://www.hrw.org/report/2005/06/14/decisions-denied/womens-accesscontraceptives-and-abortion-argentina

Møllmann, M. (2007). Over their dead bodies denial of access to emergency obstetric care and therapeutic abortion in Nicaragua. Retrieved from https://www.hrw.org/report/2007/10/01/overtheir-dead-bodies/denial-access-emergency-obstetric-care-and-therapeutic

Molyneux, M. (2001). Women's movements in international perspective: Latin America and beyond. London: Palgrave.

Molyneux, M. (2006). Mothers at the service of the new poverty agenda: Progresa/oportunidades, Mexico's conditional transfer programme. Social Policy \& Administration, 40(4), 425-449. doi:10.1111/j.1467-9515.2006.00497.x

Monthly Ranking of Women in National Parliaments. (2021). Monthly ranking of women. Retrieved from https://data.ipu.org/women-ranking?month=1\&year=2021

Navarro, M. and Bourque, S. (1998). Fault lines of democratic governance: A gender perspective. In F. Agüero and J. Stark (Eds.), Fault lines of democracy in post-transition Latin America (pp.175202). North-South Center Press at the University of Miami.

Nelson, A. A. (2002). Political bodies: Gender, history, and the struggle for narrative power in recent chilean literature. Bucknell University Press.

Pateman, C. (1988). Sexual contract. California: Standford University Press.

Peschard, J. (2003). The quota system in Latin America: General overview (The Implementation of Quotas: Latin American Experiences Workshop Report, IDEA). Retreived from https://www.idea.int/sites/default/files/publications/implementation-of-quotas-latin-americanexperiences.pdf

Phillips, A. (2012). Demokrasinin cinsiyeti (Çev. A. Türker). İstanbul: Metis Yayınları.

Rozas, P. T. and Floru, C. (2017). Women's political participation in Latin America: Some progress and many challenges. Retrieved from https:/www.idea.int/news-media/news/women\%E2\%80\%99spolitical-participation-latin-america-some-progress-and-manychallenges?fbclid=IwAR0oVaNBis Ndu0iEy0yRbxgyPW1zwhK3UBSt8iXltnNPcN0AH6Z-j4kciko

Schild, V. (1998). New subjects of rights? Women's movements and the construction of citizenship in the new democracies. In S. Alvarez, E. Dagnino, and A. Escobar (Eds.), Cultures of politics, politics of cultures: Re-visioning Latin American social movements (pp. 93-117). Boulder, CO: Westview Press, A Division of Harpercollins Publishers, Inc.

Schild, V. (2000). Neo-liberalism's new gendered market citizens: The'civilizing'dimension of social programmes in Chile. Citizenship Studies, 4(3), 275-305. https://doi.org/10.1080/713658800 
E. G. Çamur, "Between Neoliberalism, Motherhood and Dictatorship: Women's Citizenship and Participation in Latin America"

Squires, J. (2007). The new politics of gender equality. Macmillan International Higher Education.

Stephen, L. (1997). Women and social movements in Latin America, power from below. University of Texas Press.

The Rapist Is You!': Why a Chilean Protest Chant is Being Sung Around the World. (2020). The rapist is you!. https://www.theguardian.com/society/2020/feb/03/the-rapist-is-you-chilean-protest-songchanted-around-the-world-un-iolador-en-tu-camino

The World's Abortion Laws. (2021). Abortion laws. Retrieved from https://reproductiverights.org/worldabortionlaws

Waylen, G. (2000). Gender and democratic politics: A comparative analysis of consolidation in Argentina and Chile. Journal of Latin American Studies, 32(3), 765-793. doi: 10.1017/S0022216X00005939

Willmott, C. (2002). Constructing citizenship in the Poblaciónes of Santiago, Chile: The role of reproductive and sexual rights. In N. Craske and M. Molyneux (Eds.), Gender and the politics of rights and democracy in Latın America (pp. 124-148). London: Palgrave Macmillan. 